\title{
Kesejahteraan Siswa: Faktor Pendukung dan Penghambatnya
}

\author{
Ana Ianah $^{1^{*}}$, Rena Latifa ${ }^{2}$, Risatianti Kolopaking ${ }^{3}$, Muhamad Nanang Suprayogi ${ }^{4}$ \\ 1,2,3 Psychology Department, UIN Syarif Hidayatullah Jakarta \\ ${ }^{4}$ Psychology Department, Faculty of Humanities, Universitas Bina Nusantara \\ Jakarta 11480, Indonesia \\ anaianah19@mhs.uinjkt.ac.id; rena.latifa@uinjkt.ac.id; risatianti.kolopaking@uinjkt.ac.id; \\ msuprayogi@binus.edu
}

*Correspondence: anaianah19@mhs.uinjkt.ac.id

\begin{abstract}
The efforts to improve student wellbeing are one of the main concerns in the current educational process. There are a lot of research on wellbeing, but there is still very little research on the wellbeing of children and adolescents, especially in the school context. This paper aims to examine internal and external factors for improving student wellbeing, as well as to reveal the inhibiting factors for student wellbeing. The student wellbeing during childhood and adolescence is important because it will determine the quality of life of students in the future. The results of the study show the factors of increasing wellbeing internally are: 1. The ability to adapt; 2. Learning orientation; 3. Self-assessment; 4. Personal characteristics, while external factors are 1. Student teacher relations; 2. Relationship between children and parents; 3. Friend relations; 4. An environment that supports discipline. While the factors that inhibit wellbeing internally are: 1. Physical health, 2. Students are not maximal in learning, 3. Inadequate achievement, 4. Inadequate material needs, 5. Negative behavior, such as lazy, arrogant, shy, and naughty. While externally are 1 . The unpleasant environment 2. Receiving less pleasant treatment; 3 . Not able to actualize well.
\end{abstract}

Keyword: Student wellbeing; improving; inhibiting; external; internal.

\begin{abstract}
ABSTRAK
Upaya peningkatan kesejahteraan siswa merupakan salah satu perhatian utama dalam proses pendidikan sekarang ini. Banyak penelitian tentang kesejahteraan, namun masih minim sekali penelitian tentang kesejahteraan pada anak-anak dan remaja, terutama dalam konteks sekolah. Tulisan ini bertujuan untuk mengkaji faktor peningkatan kesejahteraan siswa dari segi internal dan eksternal, serta mengungkap faktor penghambat kesejahteraan siswa. Kesejahteraan siswa di masa anak-anak dan remaja penting, karena turut menentukan kualitas kehidupan siswa di masa mendatang. Hasil penelitian menujukkan faktor peningkatan kesejahteraan secara internal yaitu: 1. Kemampuan menyesuaikan diri; 2. Orientasi belajar; 3. Penilaian terhadap diri; 4. Karakteristik pribadi, sementara faktor eksternal yaitu; 1. Relasi guru siswa; 2. Relasi anak-orang tua; 3. Relasi teman; 4. Lingkungan yang menunjang kedisiplinan. Sementara faktor penghambat kesejahteraan secara internal yaitu: 1. Kesehatan fisik, 2. Siswa kurang maksimal dalam melakukan pembelajaran, 3. Prestasi yang kurang memadai, 4. Kebutuhan materil yang belum tercukupi, 5. Perilaku negatif, seperti; malas, sombong, pemalu dan nakal. Sementara secara eksternal yaitu 1. Lingkungan yang kurang menyenangkan 2. Mendapatkan perlakuan yang kurang menyenangkan; 3. Kurang bisa beraktualisasi dengan baik.
\end{abstract}

Kata Kunci: Kesejahteraan siswa; peningkatan; penghambat; eksternal; internal. 


\section{PENDAHULUAN}

Kesejahteraan siswa perlu diperhatikan karena merupakan indikator penting untuk merefleksikan perkembangan siswa (Elmore, 2010). Mengingat pentingnya peningkatkan kesejahteraan siswa di sekolah, maka pendidikan positif perlu diterapkan (Zhang, 2016). Young (2020) mengungkapkan jika para pendidik peduli akan kesejahteraan siswa maka akan mendorong dan menghasilkan pendidikan yang positif.

Sebagaimana lazimnya, semua orang menghendaki kehidupan yang baik dan bermakna, termasuk siswa di sekolah. Kehidupan yang baik dan bermakna itu bisa dilihat pada kondisi fisik yang sehat, kondisi psikologis yang sehat, kehidupan sosial yang harmonis, kemampuan kognitif yang memadai, juga kondisi lingkungan dan ekonomi yang layak dan terpenuhi. Kondisi itu semua menurut Grandsmith (2017) disebut sebagai kesejahteraan. Ed Diener (Ed) (2009) menyebut kesejahteraan sebagai ilmu perilaku yang mempelajari tentang evaluasi seseorang yang menilai terhadap kehidupannya sebagai sebuah bentuk evaluasi. Sementara Gillet-Swan dan Sargent (2015) mengungkapkan kesejahteraan sebagai kapasitas individu untuk mengatur ragam input baik itu konstruktif maupun yang tidak diharapkan yang mempengaruhi kondisi fisik, emosional, dan kognitif dalam merespon konteks tertentu. Kesejahteraan dideskripsikan sebagai sebuah dasar kualitas hidup dan produktifitas pada individu, keluarga, komunitas, dan bangsa, sehingga individu menjalani hidup yang berarti dan menjadi warga negara yang kreatif dan aktif' (WHO, 1998). Pada dasarnya, kesejahteraan secara umum ini tidak ada pemaknaan yang pas yang bisa diterima secara universal, karena memiliki makna konotasi yang berbeda untuk tiap individu, kelompok, ataupun budaya tertentu (WHO, 2018). Berkaitan dengan kesejahteraan siswa, hal ini mencakup kualitas kehidupan siswa di sekolah dan juga perilaku beresiko yang menghampirinya (OECD, 2009).

Masa anak-anak dan remaja lekat dengan stereotype periode bermasalah (Hurlock, 2010). Oleh sebab itu kemungkinan untuk merasa ketidakbermaknaan bisa saja dialami oleh mereka. Misalnya saja dalam tekanan stress dan kurangnya kesejahteraan siswa dalam belajar daring, per-Oktober 2020 Komisi Perlindungan Anak Indonesia (KPAI) mencatat sudah ada tiga pelajar yang menjadi korban akibat Pembelajaran Jarak Jauh (PJJ) yang kurang memperhatikan kesejahteraan siswa (Putra, 2020), diantaranya, yaitu siswa SMA di Kabupaten Gowa-Sulawesi Selatan yang nekat mengakhiri hidupnya dengan meminum racun karena diakibatkan stress dengan tugas yang menumpuk dan jaringan internet yang sering putus (Yunus, 2020).

Kejadian di atas bisa saja sebagai gambaran gunung es yang hanya sedikit nampak, namun sebetulnya banyak sekali siswa yang mengalami kurangnya kesejahteraan dalam belajar (Putra, 2020). Oleh karena alasan itu, pelu adanya upaya peningkatan kesejahteraan siswa agar siswa dapat menemukan kesejahteraannya. Masih sedikit penelitian tentang kesejahteraan anak dan remaja dalam konteks sekolah dan upaya peningkatannya serta mengungkap faktor-faktor penghambatnya. Dalam artikel ini penulis mencoba untuk melihat upaya peningkatan kesejahteraan siswa dan juga faktor-faktor penghambatnya.

\section{METODE PENELITIAN}

Penelitian ini merupakan penelitian kualitatif dengan metode penelitian studi literatur. Studi literatur menurut Zed (2004), merupakan serangkaian kegiatan yang berkenaan dengan metode pengumpulan data pustaka, membaca, mencatat, serta mengolah bahan penelitian. Data pada penelitian ini dikumpulkan dengan menggunakan penelusuran online pada jurnal-jurnal dengan tema kesejahteraan siswa (student wellbeing) yang dipublikasikan dari sejak tahun 2004 hingga 2020 sebanyak 25 artikel ditambah dengan data pendukung lain berupa informasi dari buku dan website. Data yang diperoleh kemudian dianalisis dengan menggunakan teknik analisis deskriptif untuk mengidentifikasi dan menganalisa faktor-faktor peningkatan dan penghambat kesejahteraan siswa. 


\section{HASIL DAN PEMBAHASAN}

\section{Kesejahteraan Siswa}

Pada awalnya penelitian kesejahteraan hanya muncul bagi kalangan dewasa saja, namun pada masa sekarang ini dirasa perlu melihat bahwa kesejahteraan juga dipandang penting pada masa anak-anak dan remaja (Aulia et al., 2020). Masa anak-anak dan remaja ini kelak akan berpengaruh pada kehidupan selanjutnya. Karena alasan itulah semakin berkembang tentang kesejahteraan ini bukan hanya dirasa penting pada orang dewasa saja.

Noble dkk (2008) menjelaskan bahwa kesejahteraan siswa ini sangat terkait dengan kondisi pembelajaran. Tingkat kesejahteraan siswa ditunjukkan oleh kepuasan mereka pada kehidupan ketika bersekolah, yaitu keterlibatan mereka pada proses pembelajaran, dan perilaku sosial-emosional mereka (Noble et al., 2008). Pendapat lain mengatakan bahwa kesejahteraan ini lebih menekankan pada aspek perubahan yang merangkum kualitas hidup individu dan juga kebahagiaan yang lebih menekankan pada kesejahteraan subjektif, dimana seseorang memiliki rasa yang baik dan juga tumbuh dengan baik, yaitu dari segi kesehatan ataupun mentalnya (Noble \& Mcgrath, 2012; Roffey, 2015).

\section{Faktor Peningkatan Kesejahteraan Siswa}

Pencapaian pada kesejahteraan siswa menjadi tanggungjawab sekolah, masyarakat dan keluarga (Karyani, 2008). Adapun upaya untuk peningkatan kesejahteraan siswa ini perlu dilakukan, karena kesejahteraan siswa di sekolah menjadi salah satu faktor yang menentukan sejauh mana kualitas pendidikan itu bisa dirasakan efektif oleh seluruh individu yang ada di dalamnya (Ramdani \& Prakoso, 2019). Ada dua faktor yang dapat meningkatkan kesejahteraan siswa, yaitu faktor internal dan faktor eksternal (Thoybah \& Aulia, 2020).

\section{- Faktor internal}

Faktor internal terbangunnya kesejahteraan siswa terbentuk oleh beberapa hal, yaitu: kemampuan menyesuaikan diri, orientasi belajar, penilaian tehadap diri, dan karakteristik pribadi (Thoybah \& Aulia, 2020).

Penyesuaian diri adalah suatu proses yang dilakukan oleh seorang individu untuk mengatasi dan memenuhi kebutuhan-kebutuhannya untuk mencapai sebuah keharmonisan yang terdapat di dalam diri individu maupun di dalam lingkungan (Wulandari, 2016a). Penyesuaian diri ini merupakan sebuah kemampuan pada individu dalam hal menilai dirinya secara realistik, menilai situasi secara realistik, menilai prestasi yang diperolehnya secara realistik, menerima tanggung jawab, kemandirian, mengontrol emosi, berorientasi tujuan, berorientasi keluar, penerimaan sosial, memiliki filsafat hidup, dan berbahagia (Wulandari, 2016). Hal tersebut memberikan makna bahwa semakin tinggi penyesuaian diri siswa maka semakin tinggi pula kesejahteraan psikologinya (Wulandari, 2016).

Orientasi Belajar. Orientasi belajar merupakan salah satu aspek gaya belajar, yaitu aspek metakognitifafektif yang dapat mempengaruhi hasil belajar siswa (Ayuningthyas, 2006). Siswa sebagai subjek pendidikan adalah perlu dilihat dari segi orientasi belajarnya (Setyawan \& Dewi, 2015). Sebuah penelitian menunjukkan pentingnya memasukkan ukuran kesejahteraan saat mengevaluasi peran orientasi belajar dan pencapaian (Tuominen-Soini et al., 2008). Orientasi belajar ini sangat berperan dalam mencari makna dan kemampuan empati terhadap kesejahteraan siswa (Setyawan \& Dewi, 2015). Oleh karena itu siswa harus memiliki kapabilitas dan orientasi yang efektif untuk dapat melaksanakan proses pendidikan dan pembelajaran yang mengarah pada tujuan yang hendak dicapai (Setyawan \& Dewi, 2015).

Penilaian terhadap diri. Penilaian diri adalah suatu teknik penilaian di mana siswa diminta untuk menilai dirinya sendiri berkaitan dengan status, proses dan tingkat pencapaian kompetensi yang dipelajarinya dalam mata pelajaran tertentu didasarkan atas kriteria atau acuan yang telah disiapkan (Rusilowati, 2013). Penilaian terhadap diri ini adalah dipandang jika siswa menilai suatu itu baik bagi dirinya, maka ia pun akan menunjukan performa baik pula sehingga dapat meningkatkan kesejahteraan siswa (Setyahadi, 2017). Demikian sebaliknya, jika siswa menilai bahwa sesuatu itu tidak baik baginya, maka kesejahteraannya pun menurun ( Setyahadi, 2017).

Karakteristik pribadi. Karakteristik pribadi adalah faktor intenal yang membuat perilaku seseorang konsisten pada satu waktu kepada seseorang, dan perbedaan perilaku kepada yang lain pada situasi yang komparabel (Eysenk, 1994). Pada karakteistik pribadi ini, tergantung pada karakter individu siswa itu sendiri yang akan mempengaruhi kesejahteraan pada masing-masing dirinya (Setyahadi \& Yanuvianti, 2018). Uniknya, ternyata masing-masing pribadi siswa mampu menyelesaikan masalahnya dan memiliki tingkat kesejahteraan yang berbeda-beda, tergantung pada kepribadian siswa masing-masing (Batubara, 2017). 


\section{- Faktor Eksternal}

Menurut Organization for Economic Cooperation and Development (OECD) (2009) ada beberapa hal yang dibutuhkan dalam meningkatkan kesejahteraan siswa, yaitu: dukungan guru, adanya hubungan positif dengan teman, berada di lingkungan yang dapat menunjang kedisiplinan, dan perhatian dari orang tua. Hal senada diungkapkan oleh Moore dkk (2018), bahwa lingkungan sekolah yang sehat, hubungan baik dengan teman dan keluarga merupakan substansi yang penting dalam membangun kesejahteraan siswa. Lebih detil diuraikan sebagai berikut:

Relasi guru-siswa. Sebuah penelitian menunjukan tentang hubungan guru dan siswa yang menunjukkan adanya dampak peningkatan pada kesejahteraan siswa, yaitu hubungan siswa-guru tidak hanya berfokus pada interaksi dan instruksi pada saat mengajar saja, melainkan adanya sedikit perhatian dan motivasi pada perasaan siswa (Lavy, 2020). Kesejahteraan siswa dipengaruhi oleh peran besar guru dalam menciptakan kondisi kesejahteraan siswa di sekolah dan pemerintah seharusnya tidak menentukan peran guru hanya melalui jumlah jam pelajaran saja, namun tetap ambil peran juga di luar jam pelajaran tersebut (OECD, 2017). Siswa yang bahagia cenderung melaporkan hubungan positif dengan guru mereka, serta siswa di sekolah yang mempunyai tingkat kesejahteraan di atas rata-rata nasional mendapatkan dukungan yang lebih tinggi dari gurunya daripada siswa di sekolah yang mempunyai tingkat kesejahteraan di bawah rata-rata (OECD, 2017). Jika hubungan siswa dengan guru mempunyai relasi yang positif, maka akan berpengaruh pada perkembangan motivasi siswa, prestasi siswa, dan juga menumbuhkan rasa memiliki dan bangga terhadap sekolah (Pérez et al., 2017).

Relasi anak-orang tua. Kesejahteraan siswa juga berkaitan dan berhubungan signifikan dengan relasi anak-orang tua, yaitu persepsi anak tentang komunikasi siswa dengan kedua orang tua mereka dan orang tua juga mempunyai peranan yang sangat kuat pada anak atau remaja (Bireda, 2018). Oleh karena itu perlu adanya membangun komunikasi antara anak dengan orang tua, sehingga bisa meningkatkan kesejahteraan anak/siswa (Birda, 2018).

Relasi teman. Penelitian menunjukan bahwa keterhubungan dengan teman akan memberikan efek dalam pembentukan perilaku (Rimpelä, et.al, 2020). Disisi lain, keterhubungan dengan teman juga mempunyai peranan penting dalam memprediksi kesejahteraan siswa (Moore et.al, 2018). Bukan hanya keterhubungan saja yang diperhatikan, melainkan dengan adanya dukungan kuat dari teman, maka kesejahteraan siswa akan semakin terbangun lebih kokoh lagi (Anisa, 2014).

Lingkungan yang menunjang kedisiplinan. Faktor-faktor dalam lingkungan sekolah dapat mempengaruhi kesehatan mental dan kesejahteraan siswa (Harding et al., 2019). Walaupun pada beberapa penelitian menyebutkan bahwa ada sebuah arti penting dari faktor lingkungan yang mempengaruhi kesejahteraan pada siswa, namun sayangnya hal tersebut dianggap tidaklah cukup kuat memprediksikan dikarenakan keterbatasan dalam penelitian tersebut yang menjelaskan bahwa ada faktor personal yang mempengaruhi atribut paling signifikan dalam memprediksikan kesejahteraan siswa (Ramdani, Zulmi \& Prakoso, 2019).

Faktor peningkatan kesejahteraan siswa dapat dilihat dalam table berikut:

Tabel 1: Faktor peningkatan kesejahteraan siswa.

\begin{tabular}{llll}
\hline \multicolumn{2}{c}{ Faktor Internal } & \multicolumn{1}{c}{ Faktor Eksternal } \\
\hline 1. Kemampuan menyesuaikan diri; & 1. & Relasi guru siswa; \\
2. Orientasi belajar; & 2. & Relasi anak-orang tua; \\
3. Penilaian terhadap diri; & 3. & Relasi teman; \\
4. Karakteristik pribadi. & 4. & Lingkungan yang menunjang kedisiplinan. \\
\hline
\end{tabular}

\section{Faktor penghambat kesejahteaan siswa}

Berikutnya, penting pula diketahui factor-faktor penghambat kesejahteraan siswa. Hal ini perlu diperhatikan agar factor-faktor penghambat kesejahteraan siswa dapat dihindari dan dihilangkan. Adapun faktor penghambat itu misalnya adalah kurangnya hubungan yang sehat dengan orang lain sehingga kesejahteraan siswa terganggu (Masters, 2004). Untuk lebih detilnya faktor penghambat untuk terciptanya kesejahteraan siswa ini dapat dikategorikan dalam dua factor, yaitu faktor intenal dan faktor ekstenal (Ermawan, 2014).

Penghambat kesejahteaan siswa dari faktor internal. Ermawan (2014) menyebutkan ada beberapa faktor yang menjadi penghambat kesejahteraan siswa dari segi internal, diantaranya yaitu disebabkan oleh 1). kesehatan fisik yang bermasalah, 2). kurang maksimalnya siswa dalam melakukan pembelajaran, 3). merasa belum memiliki 
prestasi yang memadai, 4). merasa belum tercukupinya kebutuhan materil siswa, dan 5). perilaku siswa yang dianggap masih merugikan diri sendiri dan orang lain seperti perilaku malas, sombong, pemalu dan nakal.

Penghambat kesejahteaan siswa dari faktor ekstenal. Adapun faktor dari luar diri siswa atau faktor eksternal yang bisa menyebabkan siswa menjadi tidak sejahtera adalah: 1). lingkungan siswa yang dirasa kurang menyenangkan untuk siswa, 2). siswa masih mendapatkan perlakuan yang dianggap kurang menyenangkan dari lingkungan dimana mereka tinggal, 3). siswa kurang bisa beraktualisasi dengan baik karena adanya pengaruh lingkungannya, misalnya larangan dari orang tua, teguran dari guru atau bahkan pengaruh teman (Ermawan, 2014).

Tabel 2. Faktor penghambat kesejahteraan siswa

\begin{tabular}{lll}
\hline \multicolumn{1}{c}{ Internal } & \multicolumn{1}{c}{ Eksteral } \\
\hline 1. Kesehatan fisik & 1. Lingkungan yang kurang menyenangkan \\
2. Siswa kurang maksimal dalam melakukan & 2. Mendapatkan perlakuan yang kurang menyenangkan \\
& pembelajaran & 3. Kurang bisa beraktualisasi dengan baik. \\
3. Prestasi yang kurang memadai, & \\
4. Kebutuhan materil yang belum tercukupi, & \\
5. Perilaku negatif, seperti; malas, sombong, \\
\hline
\end{tabular}

\section{KESIMPULAN}

Siswa dalam proses pendidikan perlu diperhatikan tingkat kesejahteraannya. Hal tersebut penting karena akan mereka dapat berkembang dengan maksimal, serta dapat berprestasi sebaik mungkin. Faktor-faktor peningkatan kesejahteraan siswa baik secara internal maupun secara eksternal diharapkan dapat diterapkan. Sementara factor penghambat kesejahteraan siswa baik secara internal, maupun secara eksternal diharapkan dapat dihindari dan dihilangkan. menunjang proses pembelajaran yang mumpuni, sehingga teciptanya proses pembelajaran dan pendidikan yang positif.

Demi terciptanya pendidikan yang lebih baik, perlu kiranya ada usaha dan aksi nyata untuk meningkatkan kesejahteraan siswa. Hal demikian, akan membuat siswa tidak lagi hanya sebagai objek pendidikan, melainkan melakukan perannya sebagai subjek dalam melakukan pembelajaran yang optimal, sehingga diharapkan mereka dapat berprestasi yang akan membawa manfaat bagi diri siswa, juga manfaat bagi lingkungan sekitarnya.

\section{DAFTAR PUSTAKA}

Anisa, R. (2014). Kesejahteraan Siswa Dari Keluarga Pra Sejahtera (Doctoral dissertation, Universitas Muhammadiyah Surakarta).

Aulia, F., Hastjarjo, T. D., Setiyawati, D., \& Patria, B. (2020). Student Well-being: A Systematic Literature Review. Buletin Psikologi, 28(1), 1-14. DOI: 10.22146/buletinpsikologi.42979

Ayuningthyas, A. (2006). Diduga Depresi Karena Jaringan Internet Sering Putus, Siswa SMA Bunuh Diri - Suara Sulsel. https://sulsel.suara.com/read/2020/10/17/200010/diduga-depresi-karena-jaringan-internet-sering-putus-siswa-sma-bunuh-diri?page=all

Batubara, A. (2017). Hubungan antara Religiusitas dengan Psychological Well Being ditinjau dari Big Five Personality pada Siswa SMA Negeri 6 Binjai. AL-Irsyad:Jurnal Pendidikan Dan Konseling, 7(1), 48-62. http://jurnal.uinsu.ac.id/index.php/al-irsyad/article/view/6667

Bireda, A. D., \& Pillay, J. (2018). Perceived parent-child communication and well-being among Ethiopian adolescents. International Journal of Adolescence and Youth, 23(1), 109-117. https://doi.org/10.1080/0267 3843.2017.1299016 
Diener, Ed. (Ed.). (2009). Social Indicator Reasearch Series: Assessing Well-Being; The Collected Word of Ed Diener. USA: Springer. https://books.google.co.id/books?id=UbQUq5hNQeYC\&printsec=frontcover\&dq=subjective + well + being + diener $++1984 \& h l=e n \& s a=X \& v e d=2 a h U K E w i i u c D c 4 Z n q A h X L T-$ 30KHccYAJsQ6AEwAnoECAUQAg\# $\mathrm{v}=$ onepage $\& \mathrm{q}=$ subjective $\% 20$ well $\& \mathrm{f}=$ false

Elmore, G. M., \& Huebner, E. S. (2010). Adolescents' satisfaction with school experiences: Relationships with demographics, attachment relationships, and school engagement behavior. Psychology in the Schools, 47(6), 525-537. doi: 10.1002/pits.20488

Ermawan, N. (2014). Faktor-faktor penghambat kesejahteraan siswa smp muhammadiyah di surakarta (Doctoral dissertation, Universitas Muhammadiyah Surakarta).

Eysenck, M. W. (1994). Individual differences: Normal and abnormal. Psychology Press.

Gillett-Swan JK and J Sargeant (2015) Wellbeing as a process of accrual: Beyond subjectivity, and beyond the moment. Social Indicators Research 121(1): 135-148.

Grant-Smith, D., Gillett-Swan, J., \& Chapman, R. (2017). WIL wellbeing: Exploring the impacts of unpaid practicum on kesejahteraan siswa.

Harding, S., Morris, R., Gunnell, D., Ford, T., Hollingworth, W., Tilling, K., ... \& Campbell, R. (2019). Is teachers' mental health and wellbeing associated with students' mental health and wellbeing?. Journal of affective disorders, 242, 180-187.

Hurlock, E. B. (2010). Psikologi perkembang-an: Suatu pendekatan sepanjang rentang kehidupan (Alih Bahasa Istiwidayanti) (Edisi Kelima). Jakarta: Erlangga

Karyani, U. (2008). Keluarga Sebagai Ranah Utama Kesejahteraan Siswa (Issue 2005, pp. 206-213).

Lavy, S., \& Naama-Ghanayim, E. (2020). Why care about caring? Linking teachers' caring and sense of meaning at work with students' self-esteem, well-being, and school engagement. Teaching and Teacher Education, 91, 103046. https://doi.org/10.1016/j.tate.2020.103046

Masters, G. N. (2004). Conceptualising and Researching Student Wellbeing. Australian Council for Educational Research, 2004, 1-6. http://research.acer.edu.au/research_conference_2004\%0Ahttp://research.acer. edu.au/research_conference_2004\%5Cnhttp://research.acer.edu.au/research_conference_2004/1

Moore, G. F., Cox, R., Evans, R. E., Hallingberg, B., Hawkins, J., Littlecott, H. J., ... \& Murphy, S. (2018). School, peer and family relationships and adolescent substance use, subjective wellbeing and mental health symptoms in wales: a cross sectional study. Child indicators research, 11(6), 1951-1965. https://doi. org/10.1007s12187-017-9524-1

Noble, T., McGrath, H., Wyatt, T., Carbines, R., Robb, L., \& International, E. (2008). Employment and Workplace Relations Scoping study into approaches to student wellbeing. FINAL REPORT. Seven, November, 177.

Noble, T., \& Mcgrath, H. (2012). Wellbeing and Resilience in Young People and the Role of Positive Relationships. 17-33. https://doi.org/10.1007/978-94-007-2147-0

OECD. (2009). Doing better for children (www.oecd.org/els/social/childwellbeing)

OECD. (2009). Program for International Student Assesment https://www.oecd.org/pisa/Well-being-Infographics.pdf

OECD. (2017). Most teenagers happy with their lives but schoolwork anxiety and bullying an issue. https://www. oecd.org/newsroom/most-teenagers-happy-with-their-lives-but-schoolwork-anxiety-and-bullying-anissue.htm

Pérez, A., Santamaria, E. K., Operario, D., Tarkang, E. E., Zotor, F. B., Cardoso, S. R. de S. N., Autor, S. E. U., De, I., Dos, A., Vendas, O. D. E., Empresas, D. A. S., Atividades, P. O., Artigo, N., Gest, G. N. R. M. D. E., Para, D. E. F., Miranda, S. F. da R., Ferreira, F. A. A., Oliver, J., Dario, M., .. Volk, J. E. (2017). No 主観的健康感を中心とした在宅高齢者における 健康関連指標に関する共分散構 造分析Title. In BMC Public Health (Vol. 5, Issue 1). https://ejournal.poltektegal.ac.id/index.php/ siklus/article/view/298\%0Ahttp://repositorio.unan.edu.ni/2986/1/5624.pdf\%0Ahttp://dx.doi. org/10.1016/j.jana.2015.10.005\%0Ahttp://www.biomedcentral.com/1471-2458/12/58\%0Ahttp:// ovidsp.ovid.com/ovidweb.cgi?T=JS\&P 
Putra, I. P. (2020). Renggut Tiga Nyawa, Kemendikbud Didesak Kaji Ulang Model PJJ - Medcom.

Ramdani, Zulmi \& Prakoso, B. H. (2019). Integritas Akademik: Prdiktor Kesejahteraan Siswa Di Sekolah. Article in Indonesian Journal of Educational Assesment. https://doi.org/10.26499/ijea.v2i1.14

Roffey, S. (2015). Becoming and agent of change for school and student well-being. Education and Child Psychology, March.

Rusilowati, A. (2013). Pengembangan Intrumen Nontes. Seminar Nasional Evaluasi Pendidikan Tahun 2013, 1, 7-21.

Setyahadi, Savitri Yasmin M. Y. (2017). Studi Deskriptif Mengenai Student Well-Being pada Siswa SMA X Bandung Descriptive. Prosiding Psikologi, 4(1), 32-37.

Setyawan, I., \& Dewi, K. S. (2015). Kesejahteraan Sekolah Ditinjau Dari Orientasi Belajar Mencari Makna Dan Kemampuan Empati Siswa Sekolah Menengah Atas. Jurnal Psikologi Undip, 14(1), 9-20. https://doi.org/10.14710/jpu.14.1.9-20

Setyahadi, S. Y., \& Yanuvianti, M. (2018). Studi deskriptif mengenai student well-being pada siswa SMA X Bandung. Prosiding psikologi. ISSN: 2440-6448

Thoybah, N., \& Aulia, F. (2020). Determinan Kesejahteraan Siswa Di Indonesia (Sebuah Tinjauan Literatur). Jurnal Riset Psikologi, 2020(2).

WHO. (1998). Wellbeing measures in primary health care/the DEPCARE project: report on a WHO meeting, Stockholm, Sweden 12-13 February 1998. In Wellbeing measures in primary health carel the DEPCARE project: report on a WHO meeting, Stockholm, Sweden 12-13 February 1998.

WHO. (2018). World Health Organization, Promotion of mental well-being. In Searo. http://www.searo. who.int/entity/mental_health/promotion-of-mental-well-being/en/

Wulandari, S. (2016). Hubungan Antara Kesejahteraan Psikologis dan Penyesuaian Diri Siswa Kelas X SMK Santa Maria Jakarta. Jurnal Psiko-Edukasi, 14(2), 94-100.

Young, T., Macinnes, S., Jarden, A., \& Colla, R. (2020). The impact of a wellbeing program imbedded in university classes: the importance of valuing happiness, baseline wellbeing and practice frequency. Studies in Higher Education, 1-20. https://doi.org/10.1080/03075079.2020.1793932

Yunus, Muhamad. (2020). Diduga Deprsi Karena Jaringan Internet Sering Putus, Siswa SMA Bunuh Diri. Suarasulsel.id. 17 Oktobe 2020. 20.00

Zed, Mestika. (2004). Metode Penelitian Kepustakaan. Jakarta: Yayasan Obor Indonesia.

Zhang, Y. (2016). Making students happy with wellbeing-oriented education: Case study of a secondary school in China. The Asia-Pacific Education Researcher, 25(3), 463-471. https://doi.org/10.1007/ s40299-016-0275-4 